\title{
Morphological and physiological responses of açaí seedlings subjected to different watering regimes
}

\author{
Walter V. D. Silvestre ${ }^{1}$, Hugo A. Pinheiro ${ }^{2}$, Rodrigo O. R. de M. Souza ${ }^{1}$ \& Lenilson F. Palheta ${ }^{1}$ \\ ${ }^{1}$ Universidade Federal Rural da Amazônia/Instituto de Ciências Agrárias. Belém, PA. E-mail: walter.silvestre@ufra.edu.br (Corresponding author); \\ rodrigo.souza@ufra.edu.br; eng-flo-lenilson@hotmail.com \\ ${ }^{2}$ Universidade Federal Rural da Amazônia/Instituto Socioambiental e dos Recursos Hídricos. Belém, PA. E-mail: hugo.pinheiro@ufra.edu.br
}

\section{Key words:}

waterlogging

growth

water deficit

Euterpe oleracea

\begin{abstract}
A B S T R A C T
Seedlings of açaí obtained from plant material native to floodplains (from Laranjeira and Muaná) and adapted to upland areas (cv. BRS-Pará and ecotype Hideo) were cultivated between March and October 2013 in a greenhouse, to test the hypothesis that water requirement for seedling production varies according to the origin of plant material. The seedlings were subjected to watering regimes corresponding to 40, 70, 100 and $130 \%$ of field capacity. Regardless of plant material, the production of vigorous seedlings was feasible only under irrigation of 100 and $130 \%$ of field capacity. The seedlings produced under $130 \%$ of field capacity showed higher plant height, stem diameter, number of leaves, total leaf area, leaf and root biomass, total plant biomass and root/shoot ratio than those produced under $100 \%$ of field capacity. The former also showed higher net $\mathrm{CO}_{2}$ assimilation rate, lower stomatal conductance and transpiration and higher instantaneous water use efficiency. In conclusion, the water requirement to produce vigorous seedlings of açaí does not vary within plant material and more vigorous seedlings are produced under irrigation of $130 \%$ of field capacity.
\end{abstract}

\section{Palavras-chave:}

alagamento

crescimento

déficit hídrico

Euterpe oleracea

\section{Respostas morfológicas e fisiológicas de mudas de açaizeiros submetidas à diferentes regimes hídricos}

\section{R E S U M O}

Mudas de açaizeiro produzidas a partir de materiais vegetais oriundos de várzea (procedência Laranjeira e Muaná) e adaptadas às áreas de terra firme (cv. BRS-Pará e cotipo Hideo) foram cultivadas entre março e outubro de 2013, em viveiro, para testar a hipótese de que a demanda de água para a produção de mudas vigorosas varia em função da origem do material vegetal. As mudas foram submetidas a regimes hídricos correspondentes a 40, 70,100 e $130 \%$ da capacidade de campo. Independente do material vegetal, a produção de mudas vigorosas foi viável apenas nos regimes hídricos de $100 \%$ e $130 \%$ da capacidade de campo; desses, as mudas produzidas sob $130 \%$ da capacidade de campo apresentaram maior altura, diâmetro do caule, número de folhas, área foliar total, biomassa de raízes e folhas, biomassa total e razão raiz parte aérea; além disto, apresentaram maior taxa de assimilação líquida de $\mathrm{CO}_{2}$, menor condutância estomática e transpiração e maior eficiência instantânea do uso da água; concluindo, a demanda hídrica para produção de mudas de açaizeiro não varia com a origem do material vegetal e a produção de mudas mais vigorosas se dá pelo uso de irrigação correspondente a $130 \%$ da capacidade de campo. 


\section{INTRODUCTION}

Açaí (Euterpe oleraceae Mart.) is a very important fruit in the food chain of northeastern populations, especially in the state of Pará, constituting the staple food of riverside and low-income populations (Santana \& Costa, 2008). Due to the relevant nutritive value of the pulp, which has high concentrations of vitamins, fibers, fats and anthocyanins, besides antioxidant properties (Menezes et al., 2008), the consumption of açaí has substantially increased. As a consequence, an increase in fruit production has been observed over the last decade (SAGRI, 2015a, b), also stimulated by the growing demand of countries such as the United States, Japan and South Korea (CONAB, 2015).

Despite its evident economic potential, the production of açaí fruits comes mainly from the extractive exploitation of native trees, which naturally occur in Amazonian lowlands (Homma et al., 2006). However, part of the açaí fruit production comes from commercial plantations usually installed in upland areas, without the use of irrigation, thus depending exclusively on rainfall, or with the use of empirically managed irrigation (Homma et al., 2006). Such scenario tends to change over time, due to the development of new management techniques and employment of plant materials more adapted to upland areas, such as the cultivar BRS-Pará (Conforto \& Contin, 2009; Oliveira \& Farias Neto, 2004) and the ecotype Hideo.

In the current scenario, one of the greatest problems associated with the expansion of açaí plantations is the lack of seedlings, in quantity and quality, in order to meet the demand of the producers. This problem is partially due to the lack of adequate management in nursery operations, especially regarding seedlings irrigation, which has been totally empirical, without any criterion to guide the amount of water to be daily applied.

The use of irrigation systems for seedlings production is a management technique widely used for many crops. However, for irrigation to be efficient and the seedling to be able to express its total potential development, it is essential to take into consideration crop water demand, which considerably varies among dicotyledons (Fachini et al., 2004; Vellini et al., 2008; Carvalho et al., 2011) and monocotyledons (Barcelos et al., 2001; Ramos et al., 2002; Alves Júnior et al., 2005). The water demand necessary for the production of açaí seedlings that meet the patterns of morphological quality and vigor regulated by the norm (Brasil, 1997) has not been determined yet.

Considering that the açaí palm has its center of dispersion in the Amazonian lowlands and that soil water availability is not limiting due to the daily floods caused by the tides (Parolin et al., 2004), it is assumed that this crop is very demanding in water during its entire cycle, including the seedling stage. On the other hand, the phenotypical selection of materials more adapted to upland areas (such as the cv. 'BRS Pará) suggests that these plants can grow and produce in areas of lower water availability.

Given the above, doubts on the water demand of açai seedlings according to the origin of the plant material (lowland or upland) have raised the hypothesis that materials adapted to upland conditions would be less demanding in water during the formation of seedlings, compared with materials native to lowlands. In order to test this hypothesis, morpho-physiological responses of lowland açaí seedlings and materials adapted to upland areas were evaluated under different watering regimes, with the aim of (i) verifying whether the origin of the material influences water demand for the formation of vigorous seedlings and (ii) indicating, if possible, the best irrigation depth for the formation of vigorous açaí seedlings.

\section{Material AND Methods}

The study was conducted from March to October 2013, in a greenhouse covered with $100-\mu \mathrm{m}$ polyethylene film treated against UV radiation, at the Institute of Agricultural Sciences of the Federal University of Amazônia, in Belém-PA, Brazil ( $1^{\circ}$ $27^{\prime} 19^{\prime \prime} \mathrm{S} ; 48^{\circ} 26^{\prime} 19^{\prime \prime} \mathrm{W}$ ). The local climate is Afi, according to Köppen's classification. The seedlings of the four plant materials were produced using seeds. For lowland materials, the seeds were obtained from local markets in the islands of Muaná ( $1^{\circ} 19^{\prime} 46^{\prime \prime} \mathrm{S} ; 4^{\circ} 17^{\prime} 0^{\prime \prime} \mathrm{W}$ ) and Laranjeira (1³1' 2" S; $\left.48^{\circ} 31^{\prime} 7^{\prime \prime} \mathrm{W}\right)$ in Northern Pará, which are approximately 98 $\mathrm{km}$ distant from each other on a straight line. These materials do not constitute varieties, cultivars or ecotypes and were used in the experiment to guarantee the lowland origin; hereinafter, they will be referred to as "Muaná origin" (or simply Muaná) and "Laranjeira origin" (or simply Laranjeira). The materials adapted to upland areas came from seeds of the cv. BRS-Pará (registration $n^{\circ} 11.300 \mathrm{RNC} / \mathrm{MAPA}$, provided by the Embrapa Eastern Amazon, Belém, PA) and the ecotype Hideo (obtained from a local producer, in Santa Izabel, PA).

The seedlings were produced on polyethylene trays (50 x $33 \times 10 \mathrm{~cm}$ ) using coconut fiber (Golden Mix 87, Sococo Agroindústria da Amazônia, Ananindeua-PA, Brazil) as a substrate. After 47 days of sowing, seedlings with only one closed leaf (known as "toothpick seedlings") were transferred to polyethylene bags $(15 \times 25 \mathrm{~cm})$ containing a mix of soil and weathered poultry litter $(2.5: 1 ; \mathrm{v} / \mathrm{v})$. The soil used as a substrate was a medium-textured Yellow Latosol, which was air-dried and sieved. Seedlings were daily irrigated using pressurecompensating drippers (PCJ, Netafim, São Paulo, Brazil), with flow rate of $1.92 \mathrm{~L} \mathrm{~h}^{-1}$ per emitter. The dripper was adjusted in order to maintain the soil close to field capacity (FC) and the volume of water was determined through the gravimetric method (Klar et al., 1966).

Foliar fertilizations with macro and micronutrients were performed by applying a solution of the commercial product FHHF (Heringer, São Paulo, Brazil) at the proportion of $4 \mathrm{~g} \mathrm{~L}^{-1}$. The applications were performed every 30 days from the transplantation to the definitive bags, using $3.9 \mathrm{~mL}$ of the solution per plant.

The experiment started when seedlings showed one cotyledon leaf, mean height of approximately $10 \mathrm{~cm}$ from the collar base to the tip of the petiole and mean collar diameter of $4.5 \mathrm{~mm}$. The seedlings were subjected to different watering regimes (WR) corresponding to daily water replenishments of $40,70,100$ (control) and $130 \%$ of field capacity (FC). The WRs were established through the differential regulation of the operating time of the drippers. The water volume applied in each WR was calculated always after weighing the experimental 
units (bag + seedling + substrate), based on the methodology of Klar et al. (1966). Irrigations were daily performed, between 7:30 and 8:00 a.m.

During the experiment, daytime means of air temperature $\left(\mathrm{T}_{\text {air }}\right.$ ), relative air humidity $(\mathrm{RH})$ and incident radiation (IR), determined by an automated weather station (HOBO U12012, Onset Computer Corporation, Bourne, USA), were respectively $34{ }^{\circ} \mathrm{C}, 61 \%$ and $390 \mu \mathrm{mol} \mathrm{m} \mathrm{m}^{2}$. The mean vapor pressure deficit, determined according to Murray (1967), was $2.3 \mathrm{kPa}$.

Plants were evaluated before treatment application (Day 0 ) and at 45, 90, 135 and 180 days after WR application. The period of the experiment (180 days) was determined based on the normative regulation for the production of açaí seedlings (Brasil, 1997). On each evaluation date, the following variables were determined: plant height $(\mathrm{PH})$, collar diameter $(\mathrm{CD})$, number of leaves (NL), total leaf area (TLA), leaf dry matter (LDM), root dry matter (RDM), total dry matter (TDM), water potential $\left(\Psi_{\mathrm{w}}\right)$ and gas exchanges.

$\mathrm{PH}$ was measured using a ruler from the collar base to the petiole tip of the highest leaf. CD was determined with a digital caliper and NL through direct count of the emerged leaves.

Net $\mathrm{CO}_{2}$ assimilation (A), stomatal conductance to water vapor $\left(g_{s}\right)$ and transpiration $(E)$ were determined with an infrared gas analyzer (LCpro, ADC Bioscientific Ltd., Hoddesdon, RU) from 9 and $10 \mathrm{~h}$, under ambient $\mathrm{CO}_{2}$ concentration and photosynthetically active radiation of 900 $\mu \mathrm{mol} \mathrm{m} \mathrm{m}^{-2} \mathrm{~s}^{-1}$. Instantaneous water use efficiency (A/E) was calculated as the ratio between $\mathrm{A}$ and $\mathrm{E}$. Immediately after the evaluation of gas exchanges, the same leaf was collected for the determination of $\Psi_{w}$, using a Scholander-type pressure chamber (m 670, Pms Instrument Co., Albany, USA) (Pinheiro et al., 2008).

After the determination of the above mentioned variables, the seedlings were removed from the bags and separated into roots and shoots. Leaves were separated from the petioles and leaf blades were digitized using a scanner for the determination of leaf area, with the program Image (v.1.47, National Institute of Mental Health, Bethesda, USA). TLA was calculated as the sum of all the folioles. The root system was carefully washed in running water, using a fine-screen sieve, in order to remove the substrate. Then, folioles, petioles and root system were placed in paper bags and dried in a forced-air oven at $70{ }^{\circ} \mathrm{C}$ until constant mass, for the determination of their respective dry matters. LDM was calculated as the sum of leaf blade dry matter (LBDM) and petiole dry matter (PDM). TDM was calculated as the sum of RDM and LDM; AFE, as the ratio between TLA and LBDM, and R/S, as the ratio between RDM and LDM.

The experiment was conducted in a completely randomized design and the treatments consisted of combinations between WR (40, 70, 100 and 130\% FC), plant materials (Muaná, Laranjeira, BRS-Pará and Hideo) and evaluation periods (0, $45,90,135$ and 180 days after WR differentiation), with five replicates per treatment. One plant per bag was considered as an experimental replicate. Statistical analysis for morphological and physiological data was performed only at the end of the experiment (day 180) in order to compare the final quality of the produced seedlings as a function of the WRs. The data were subjected to ANOVA and the comparisons of means were performed through the Newman-Keuls test $(\mathrm{p}<0.05)$ using the program SAEG v. 9.1 (SAEG, 2007).

\section{Results AND Discussion}

The watering regimes of 40 and $70 \%$ FC caused lower plant growth in all materials (Figures 1 and 2). This response occurred due to the lower values of $\Psi_{w}, \mathrm{~A}, \mathrm{~g}_{\mathrm{s}}$ and $\mathrm{E}$ shown by the plant materials at the days 45 (40\% FC) and $90(70 \%$ FC) (Figure 3). Under water deficit, the reduction in $\Psi_{w}$ leads to greater stomatal closure in order to reduce the loss of water through transpiration, but the lower $g_{s}$ increases the resistance to $\mathrm{CO}_{2}$ flow into the leaves, decreasing A (Chaves et al., 2009). Reduction in $\Psi_{w}$, combined with reductions in $\mathrm{A}, \mathrm{g}_{\mathrm{s}}$ and $\mathrm{E}$, was also reported in coconut (Gomes et al., 2010), peach palm (Ramos et al., 2002; Alves Júnior et al., 2005) and oil palm (Suresh et al., 2010; Silva et al., 2016), subjected to water deficit with negative effects on vegetative growth. WRs of 40 and $70 \%$ favor the death of $100 \%$ of the plants from all the materials at 45 and 90 days of experiment, respectively (Figures 1 and 2); thus, these WR values make the production of açaí seedlings unviable. Such high mortality of seedlings under water restriction may have been due to a combined effect of the severity of the stress, resulting from the limited daily replenishment of water at the WR of 40 and 70\% FC and especially from the period in which plants were subjected to these WRs (45 and 90 days). The sensitivity of açaí seedlings to water deficit was also evidenced in seedlings planted in areas of secondary vegetation in the municipality of Bragança-PA, when a high mortality of seedlings (90\%) occurred in the dry months (Sousa \& Jardim, 2007b).

From 90 days of experiment on, the seedlings of all plant materials subjected to the watering regimes of 100 and $130 \%$ FC showed more expressive increments in $\mathrm{PH}, \mathrm{CD}, \mathrm{NL}$ and TLA (Figure 1). Indeed, increments in LDM, RDM and TDM were also observed from 90 days on, especially in seedlings under 130\% FC (Figure 2). On the day 180, PH and CD did not differ $(\mathrm{p}>0.05)$ between plant materials subjected to WR of $100 \%$ FC, but at the WR of $130 \%$ FC, the highest PH mean was observed for BRS-Pará and the lowest one for Hideo, while the highest CD mean was observed for Hideo and the lowest one for BRS-Pará (Table 1). According to WR effects on each plant material, the results indicate that only the WR of $130 \%$ FC induced the formation of seedlings with greater $\mathrm{PH}$ and $\mathrm{CD}$, and means that meet the determinations of the norm (Brasil, 1997).

NL mean did not differ significantly between plant materials compared under WR of $100 \%$ FC or $130 \%$ FC (Table 1); however, the effect of different WRs for a same plant material indicates that plants subjected to $130 \%$ FC show higher NL compared with plants under $100 \%$ FC (Table 1). It should be pointed out that only plants subjected to $130 \%$ FC showed, in 180 days, definitive leaves, as recommended in the norm proposed by CSM-PA (Brasil, 1997).

All plant materials subjected to WR of 40 and $70 \%$ for 45 days showed lower absolute values of TLA in comparison to those subjected to 100 or $130 \%$ FC. This effect was more evident 


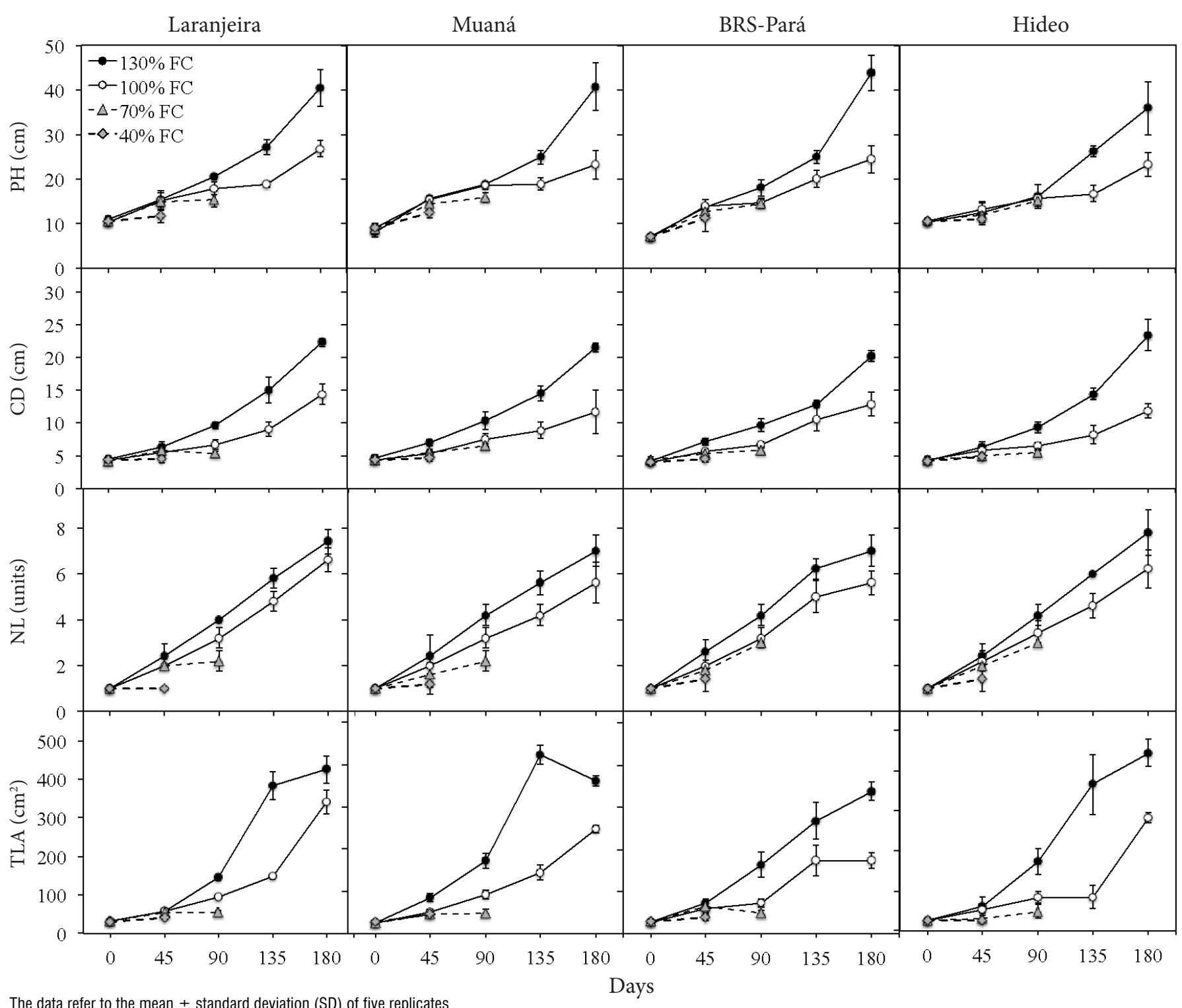

Figure 1. Plant height (PH), collar diameter (CD), number of leaves (NL) and total leaf area (TLA) in seedlings of açaí native to lowland areas (Laranjeira and Muaná) and adapted to upland areas (cv. BRS-Pará and ecotype Hideo) cultivated under different watering regimes

Table 1. Morphology of shoots (plant height - PH; collar diameter - CD; number of leaves - NL and total leaf area - TLA) of seedlings of açaí native to lowland areas (Laranjeira and Muaná) and adapted to upland areas (cv. BRS-Pará and ecotype Hideo) cultivated under different watering regimes ${ }^{\#}$

\begin{tabular}{|c|c|c|c|c|c|}
\hline \multirow{2}{*}{$\begin{array}{c}\text { Plant } \\
\text { material }\end{array}$} & \multirow{2}{*}{$\begin{array}{l}\text { Watering regime } \\
(\% \mathrm{FC})\end{array}$} & \multicolumn{4}{|c|}{ Variables } \\
\hline & & $\mathrm{PH}(\mathrm{cm})$ & CD (mm) & NL (Unit) & TLA $\left(\mathrm{cm}^{2}\right)$ \\
\hline \multirow{2}{*}{ Laranjeira } & 100 & $26.8 \pm 1.9 \mathrm{Ba}$ & $14.4 \pm 1.6 \mathrm{Ba}$ & $6.6 \pm 0.54 \mathrm{Ba}$ & $341.4 \pm 21.3 \mathrm{Ba}$ \\
\hline & 130 & $40.5 \pm 4.2 \mathrm{Aab}$ & $22.3 \pm 0.6$ Aab & $7.4 \pm 0.54 \mathrm{Aa}$ & $425.7 \pm 35.8 \mathrm{Aa}$ \\
\hline \multirow{2}{*}{ Muaná } & 100 & $23.2 \pm 3.2 \mathrm{Ba}$ & $11.7 \pm 3.3 \mathrm{Ba}$ & $5.6 \pm 0.90 \mathrm{Ba}$ & $246.6 \pm 28.7 \mathrm{BC}$ \\
\hline & 130 & $40.8 \pm 5.3 \mathrm{Aab}$ & $21.4 \pm 0.7 \mathrm{Aab}$ & $7.0 \pm 0.70 \mathrm{Aa}$ & $362.4 \pm 27.4 \mathrm{Ab}$ \\
\hline \multirow{2}{*}{ BRS-Pará } & 100 & $24.4 \pm 3.1 \mathrm{Ba}$ & $12.8 \pm 1.8 \mathrm{Ba}$ & $5.5 \pm 0.54 \mathrm{Ba}$ & $173.4 \pm 28.3 \mathrm{Bd}$ \\
\hline & 130 & $43.8 \pm 4.0 \mathrm{Aa}$ & $20.2 \pm 0.9 \mathrm{Ab}$ & $7.0 \pm 0.70 \mathrm{Aa}$ & $338.1 \pm 14.5 \mathrm{Ab}$ \\
\hline \multirow{2}{*}{ Hideo } & 100 & $23.3 \pm 2.6 \mathrm{Ba}$ & $11.9 \pm 1.2 \mathrm{Ba}$ & $6.2 \pm 0.83 \mathrm{Ba}$ & $282.8 \pm 31.8 \mathrm{Bb}$ \\
\hline & 130 & $35.9 \pm 6.1 \mathrm{Ab}$ & $23.4 \pm 2.4 \mathrm{Aa}$ & $7.8 \pm 1.00 \mathrm{Aa}$ & $444.2 \pm 45.6 \mathrm{Aa}$ \\
\hline
\end{tabular}

\# The data refer to the evaluations at the end of the experiment (day180) and represent the mean \pm standard deviation (SD) of five replicates

Uppercase letters compare the same plant material at the two different watering regimes. Lowercase letters compare different plant materials evaluated under the same watering regime. Different uppercase and lowercase letters indicate statistical difference between the means (Newman-Keuls, $P<0.05$ )

from 90 days on (Figure 1). Since there was no leaf abscission, the lower TLA in plants under water deficit can be explained by the lower NL emerged during the experimental period and/or by the smaller expansion of folioles already emerged before the beginning of the treatments. Comparatively, a lower emergence of leaves in açaí seedlings was observed due to the decrease in rainfall during the driest period of the year (Sousa \& Jardim, $2007 \mathrm{a}$ ) and reductions of up to $31 \%$ in TLA of açaí seedlings were observed in plants subjected to two cycles of water deficit induced by the suspension of irrigation (Mar et al., 2013). 


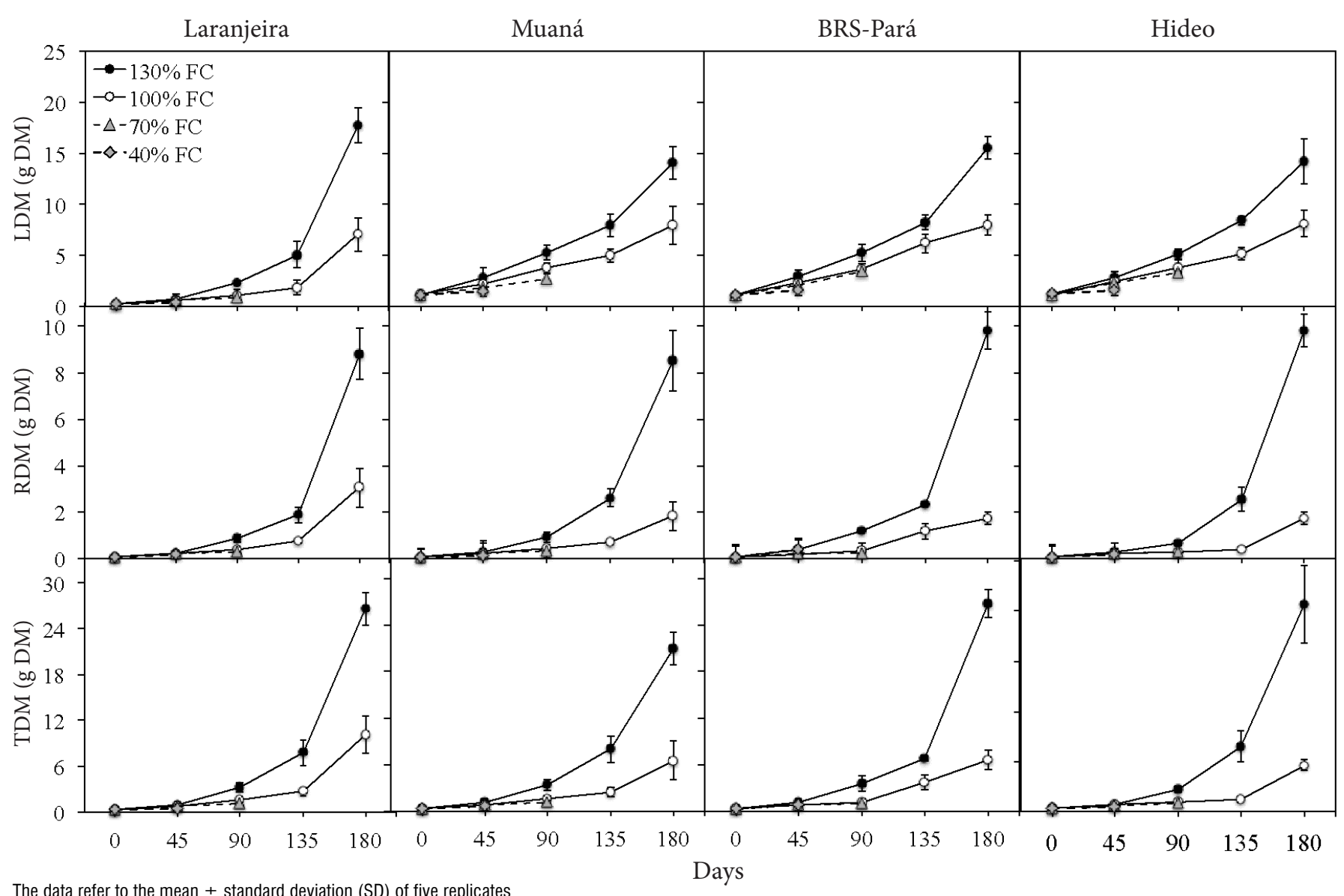

The data refer to the mean \pm standard deviation $(S D)$ of five replicates

Figure 2. Leaf dry matter (LDM), root dry matter (RDM) and total dry matter (TDM) in seedlings of açaí native to lowland areas (Laranjeira and Muaná) and adapted to upland areas (cv. BRS-Pará and ecotype Hideo) cultivated under different watering regimes

In plants subjected to $100 \% \mathrm{FC}$, the TLA was higher in seedlings from Laranjeira and lower in the seedlings of BRSPará; under $130 \%$ FC, the TLA was higher in seedlings from Laranjeira and the ecotype Hideo (Table 1). The effect of WR on each plant material indicates that plants subjected to $130 \%$ FC showed higher TLA than those subjected to $100 \%$ FC (Table 1). The increases of TLA in plants subjected to 100 and $130 \%$ FC can be explained by the higher NL and especially by the increase in the expansion of the leaf blade area of each foliole. Within certain limits and when water is not a limiting factor, higher TLA must favor greater photosynthetic capacity of the plant, as a whole, for increasing the efficiency of interception of light energy, necessary to the photochemical stage of photosynthesis. Additionally, higher TLA must favor the transport of water and nutrients to the shoots through the mass flow resulting from transpiration (Larcher, 2005).

LBDM means did not differ $(\mathrm{p}>0.05)$ between the seedlings of the different plant materials under 100\% FC (Table 2). Under $130 \%$ FC, LBDM means were significantly higher $(\mathrm{p}<0.05)$ in the seedlings of Laranjeira, BRS-Pará and the ecotype Hideo, in comparison to the seedlings from Muaná (Table 2). For all plant materials, LBDM was higher under $130 \%$ FC than under $100 \%$ FC (Table 2). The differences in LBDM reflect the increases in NL and TLA observed in plants subjected to $130 \%$ FC in relation to those subjected to $100 \%$ FC, as previously demonstrated with açaí seedlings under full irrigation (Mar et al., 2013).
RDM in plants cultivated under $100 \% \mathrm{FC}$ in seedlings from Laranjeira was higher $(p<0.05)$ than in the other plant materials, but did not differ between plant materials compared at $130 \%$ FC (Table 2). Notably, plants of all materials under WR of 130\% FC showed RDM expressively higher (from 290 to $570 \%$ ) than the respective plants cultivated under $100 \% \mathrm{FC}$, indicating that the former showed a more robust root system than the latter (Table 2). In addition, it was observed that R/S ratio did not differ between plant materials cultivated under $100 \%$ FC, but under $130 \%$ FC, it was significantly higher $(\mathrm{p}<0.05)$ in plants from Muaná and the ecotype Hideo (Table 2). It should be pointed out that WR of $130 \% \mathrm{FC}$ induced a significant increase in R/S ratio of plants from Muaná, the ecotype Hideo and the cv. BRS-Pará (Table 2).

Based on the results obtained for LBDM, PDM and RDM, the highest TDM in plants cultivated under $100 \%$ FC was observed in the seedlings from Laranjeira and the lowest one in seedlings of the ecotype Hideo. Under 130\% FC, TDM was higher for seedlings from Laranjeira, cv. BRS-Pará and ecotype Hideo (Table 2). The WR of $130 \%$ FC caused higher total biomass in the plants, compared with the WR of $100 \%$ FC (Table 2).

The $\Psi_{w}$ of all plant materials cultivated under 100 or $130 \%$ FC was similar along the period (Figure 3 and Table 3 ). The A of plants cultivated under $100 \% \mathrm{FC}$ was higher $(\mathrm{p}<0.05)$ for the seedlings from Laranjeira and lower for the seedlings of BRSPará, but differences between plant materials stopped occurring 


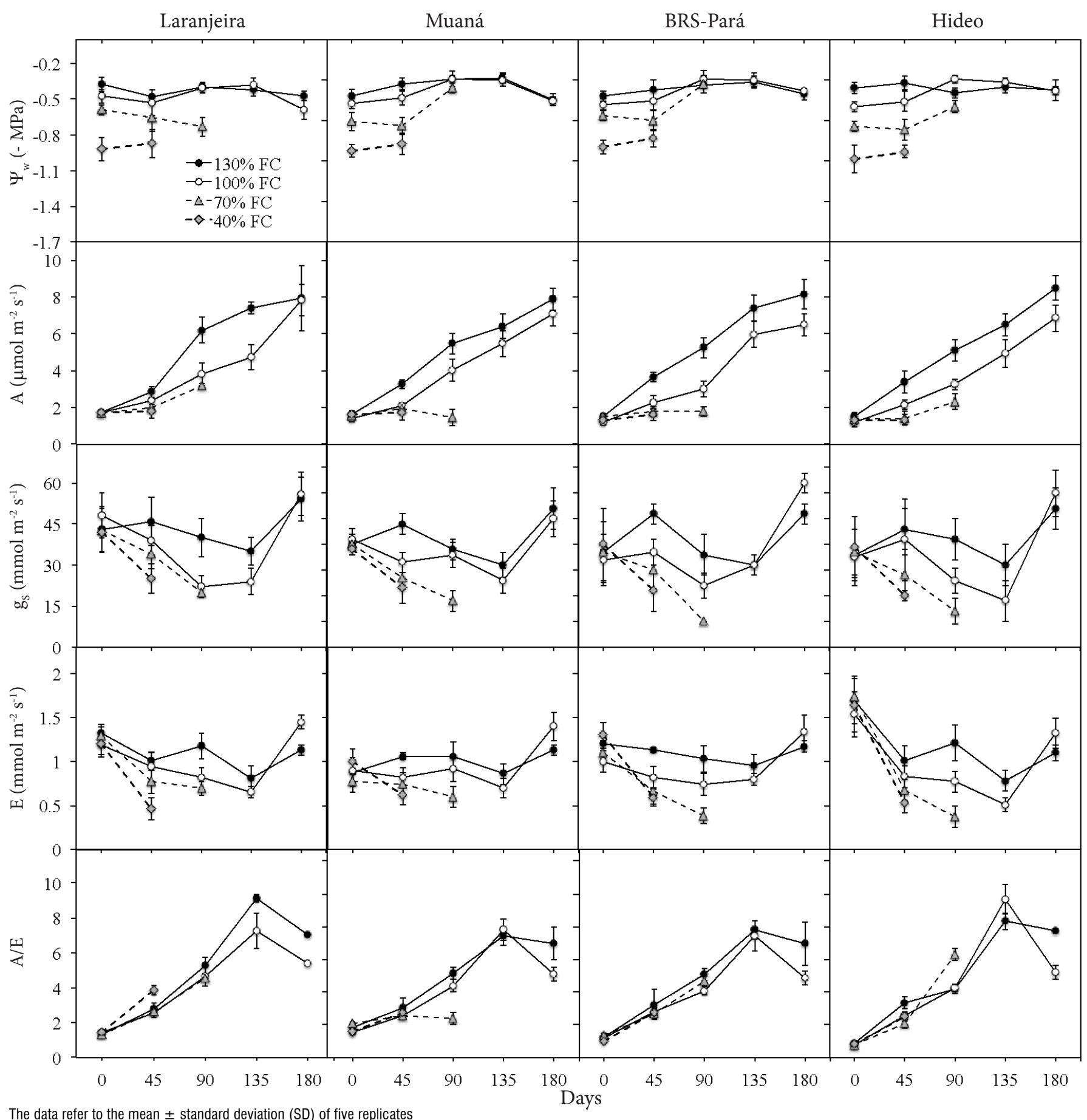

Figure 3. Water potential $\left(\Psi_{w}\right)$, net $\mathrm{CO}_{2}$ assimilation rate $(\mathrm{A})$, stomatal conductance to water vapor $\left(\mathrm{g}_{\mathrm{s}}\right)$, transpiration (E) and instantaneous water use efficiency (A/E) in seedlings of açaí native to lowland areas (Laranjeira and Muaná) and adapted to upland areas (cv. BRS-Pará and ecotype Hideo) cultivated under different watering regimes

when plants were compared under $130 \% \mathrm{FC}$ (Table 3). $\mathrm{g}_{\mathrm{s}}$, E, and $\mathrm{A} / \mathrm{E}$ did not differ between plant materials compared under the same WR ( 100 or $130 \%$ FC, Table 3 ); however, all the plant materials subjected to $130 \% \mathrm{FC}$ showed significant reductions in $\mathrm{g}_{\mathrm{s}}$ and $\mathrm{E}$, along with increases in $\mathrm{A} / \mathrm{E}$, compared with the respective plants subjected to $100 \% \mathrm{FC}$ (Table 3 ).

The differences in A, $g_{s}$ and $E$ between WRs of 100 and 130\% FC cannot be explained by the $\Psi_{w}$ values recorded for these plants from 9 to $10 \mathrm{~h}$, since they did not differ significantly along the experiment (Figure 3). However, it should be pointed out that $\Psi_{w}$ decreases along the day due to the increases in air temperature, radiation and water vapor deficit between the leaf and the atmosphere and reduction in relative air humidity (Cordeiro et al., 2009; Carvalho et al., 2013). Since the replenishment of $130 \% \mathrm{FC}$ leads to greater volume of water applied, it can be inferred that this additional water volume causes greater expansion of the wet bulb in the substrate (Maia \& Levien, 2010), allowing the occupation of micropores and part of the macropores by water, without causing hypoxia and/ or anoxia to plants, which are common in conditions of partial or prolonged flood in the soil. Thus, the water excess of $30 \%$ in relation to the WR of $100 \%$ FC means more water available to the roots, supplied by the longer time of operation of the drippers in this treatment, which must allow plants under the 
Table 2. Biomass allocation (leaf blade dry matter - LBDM; root dry matter - RDM and total dry matter - TDM) and root/ shoot ratio (R/S) of seedlings of açaí native to lowland areas (Laranjeira and Muaná) and adapted to upland areas (cv. BRS-Pará and ecotype Hideo) cultivated under different watering regimes ${ }^{\#}$

\begin{tabular}{|c|c|c|c|c|c|}
\hline \multirow{3}{*}{$\begin{array}{c}\text { Plant } \\
\text { material }\end{array}$} & \multirow{3}{*}{$\begin{array}{l}\text { Watering regime } \\
\text { (\% FC) }\end{array}$} & \multicolumn{4}{|c|}{ Variables } \\
\hline & & LBDM & RDM & TDM & $R / S$ \\
\hline & & & (g DM) & & K/J \\
\hline \multirow{2}{*}{ Laranjeira } & 100 & $3.52 \pm 0.83 \mathrm{Ba}$ & $3.05 \pm 0.85 \mathrm{Ba}$ & $10.12 \pm 2.51 \mathrm{Ba}$ & $0.43 \pm 0.02 \mathrm{Aa}$ \\
\hline & 130 & $9.24 \pm 1.09 \mathrm{Aa}$ & $8.80 \pm 1.40 \mathrm{Aa}$ & $26.59 \pm 2.70 \mathrm{Aa}$ & $0.49 \pm 0.03 \mathrm{Ab}$ \\
\hline \multirow{2}{*}{ Muaná } & 100 & $2.33 \pm 0.40 \mathrm{Ba}$ & $1.84 \pm 0.62 \mathrm{Bb}$ & $6.49 \pm 1.63 \mathrm{Bab}$ & $0.39 \pm 0.04 \mathrm{Ba}$ \\
\hline & 130 & $5.36 \pm 0.80 \mathrm{Ab}$ & $8.50 \pm 1.45 \mathrm{Aa}$ & $20.97 \pm 2.10 \mathrm{Ab}$ & $0.68 \pm 0.03 \mathrm{Aa}$ \\
\hline \multirow{2}{*}{ BRS-Pará } & 100 & $2.48 \pm 0.80 \mathrm{Ba}$ & $1.68 \pm 0.23 \mathrm{Bb}$ & $6.55 \pm 1.29 \mathrm{Bab}$ & $0.37 \pm 0.01 \mathrm{Ba}$ \\
\hline & 130 & $8.42 \pm 0.90 \mathrm{Aa}$ & $9.81 \pm 1.29 \mathrm{Aa}$ & $26.78 \pm 1.78 \mathrm{Aa}$ & $0.57 \pm 0.04 \mathrm{Ab}$ \\
\hline \multirow[b]{2}{*}{ Hideo } & 100 & $1.90 \pm 0.30 \mathrm{Ba}$ & $1.72 \pm 0.27 \mathrm{Bb}$ & $5.54 \pm 0.67 \mathrm{Bb}$ & $0.46 \pm 0.03 \mathrm{Ba}$ \\
\hline & 130 & $8.61 \pm 2.60 \mathrm{Aa}$ & $9.81 \pm 1.27 \mathrm{Aa}$ & $24.86 \pm 4.60 \mathrm{Aa}$ & $0.66 \pm 0.05 \mathrm{Aa}$ \\
\hline
\end{tabular}

\# The data refer to the evaluations at the end of the experiment (day 180) and represent the mean \pm standard deviation (SD) of five replicates

Uppercase letters compare the same plant material evaluated under two different watering regimes; Lowercase letters compare different plant materials evaluated under the same watering regime; Different uppercase and lowercase letters indicate statistical difference between the means (Newman-Keuls, $\mathrm{P}<0.05$ )

Table 3. Water potential $\left(\Psi_{\mathrm{w}}\right)$, net $\mathrm{CO}_{2}$ assimilation rate $(\mathrm{A})$, stomatal conductance to water vapor $\left(\mathrm{g}_{\mathrm{s}}\right)$, transpiration $(\mathrm{E})$ and instantaneous water use efficiency (A/E) of seedlings of açaí native to lowland areas (Laranjeira and Muaná) and adapted to upland areas (cv. BRS-Pará and ecotype Hideo) cultivated under different watering regimes\#

\begin{tabular}{|c|c|c|c|c|c|c|}
\hline \multirow{2}{*}{$\begin{array}{l}\text { Plant } \\
\text { material }\end{array}$} & \multirow{2}{*}{$\begin{array}{l}\text { Watering } \\
\text { regime } \\
(\% \mathrm{FC})\end{array}$} & \multicolumn{5}{|c|}{ Variables } \\
\hline & & $\boldsymbol{\Psi}_{\mathrm{w}}(\mathrm{MPa})$ & $A\left(\mu \mathrm{mol} \mathrm{m} \mathrm{m}^{-2} \mathrm{~s}^{-1}\right)$ & \multicolumn{2}{|c|}{$\left(\mathrm{mmol} \mathrm{m}^{-2} \mathrm{~s}^{-1}\right)$} & $A / E$ \\
\hline \multirow{2}{*}{ Laranjeira } & 100 & $-0.59 \pm 0.09 \mathrm{Aa}$ & $7.82 \pm 0.87 \mathrm{Aa}$ & $68 \pm 12 \mathrm{Aa}$ & $1.42 \pm 0.08 \mathrm{Aa}$ & $5.41 \pm 0.87 \mathrm{Ba}$ \\
\hline & 130 & $-0.47 \pm 0.04 \mathrm{Aa}$ & $7.96 \pm 0.68 \mathrm{Aa}$ & $54 \pm 9 \mathrm{Ba}$ & $1.13 \pm 0.06 \mathrm{Ba}$ & $7.05 \pm 0.68 \mathrm{Aa}$ \\
\hline \multirow{2}{*}{ Muaná } & 100 & $-0.51 \pm 0.03 \mathrm{Aa}$ & $7.11 \pm 0.67 \mathrm{Aab}$ & $60 \pm 7 \mathrm{Aa}$ & $1.40 \pm 0.18 \mathrm{Aa}$ & $5.14 \pm 0.98 \mathrm{Ba}$ \\
\hline & 130 & $-0.67 \pm 0.03 \mathrm{Ab}$ & $7.85 \pm 0.70 \mathrm{Aa}$ & $50 \pm 1 \mathrm{Ba}$ & $1.17 \pm 0.06 \mathrm{Ba}$ & $6.73 \pm 0.93 \mathrm{Aa}$ \\
\hline \multirow{2}{*}{ BRS-Pará } & 100 & $-0.51 \pm 0.08 \mathrm{Aa}$ & $6.48 \pm 0.60 \mathrm{Bb}$ & $64 \pm 12 \mathrm{Aa}$ & $1.34 \pm 0.19 \mathrm{Aa}$ & $4.87 \pm 0.37 \mathrm{Ba}$ \\
\hline & 130 & $-0.54 \pm 0.04 \mathrm{Aab}$ & $8.16 \pm 0.90 \mathrm{Aa}$ & $54 \pm 9 \mathrm{Ba}$ & $1.23 \pm 0.17 \mathrm{Ba}$ & $6.62 \pm 0.69 \mathrm{Aa}$ \\
\hline \multirow{2}{*}{ Hideo } & 100 & $-0.50 \pm 0.01 \mathrm{Aa}$ & $6.85 \pm 0.72 \mathrm{Bab}$ & $60 \pm 19 \mathrm{Aa}$ & $1.32 \pm 0.05 \mathrm{Aa}$ & $5.19 \pm 0.32 \mathrm{Ba}$ \\
\hline & 130 & $-0.50 \pm 0.04 \mathrm{Aab}$ & $8.58 \pm 0.87 \mathrm{Aa}$ & $48 \pm 4 \mathrm{Ba}$ & $1.10 \pm 0.09 \mathrm{Ba}$ & $7.82 \pm 1.17 \mathrm{Aa}$ \\
\hline
\end{tabular}

\# The data refer to evaluations at the end of the experiment (day 180) and are the mean \pm standard deviation (SD) of five replicates

Uppercase letters compare the same material evaluated under the two watering regimes; Lowercase letters compare different plant materials evaluated under the same watering regime; Different uppercase and lowercase letters indicate statistical difference between the means (Newman-Keuls, $\mathrm{P}<0.05$ )

WR of $130 \%$ FC to remain hydrated for a longer period along the day, leading to greater $\mathrm{C}$ gains in the photosynthesis.

The morphological results allow inferring that all the evaluated plant materials show better vegetative development under WR corresponding to $130 \%$ FC. Among the analysed variables, there was marked effect of WR on the increment of RDM and maintenance (Laranjeira) or increments (Muaná, Hideo and BRS-Pará) in R/S ratio, which indicate that these seedlings used most of the $\mathrm{C}$ fixed by photosynthesis for the formation of the root system, instead of the shoots. From the physiological point of view, seedlings with more robust root system and higher R/S ratio must have better capacity to adapt to the field after transplantation, because this operation tends to cause damages to the root system of the seedlings and can even lead to plant death (Larcher, 2005). Furthermore, investing in the root system is a strategy of tolerance to water stress (Pinheiro et al., 2005) and can contribute to the adaptation of seedlings during the dry months.

\section{Conclusions}

1. Açaí growth and development are not possible under water replenishments equal to or lower than $70 \%$ of field capacity.

2. Regardless of plant material origin (lowland or upland), the formation of açaí seedlings that meet the required quality standard is obtained under irrigation corresponding to $130 \%$ of field capacity.

\section{ACKnowledgments}

The authors thank Dr. Maria do Socorro Padilha (Embrapa Eastern Amazon, Belém-PA) for the donation of açaí seeds, cv. BRS-Pará.

\section{Literature Cited}

Alves Júnior, J.; Lopes, A. S.; Hernandez, F. B.T.; Santos, R. A. dos; Bergamaschine, A. F. Produção de matéria verde em pupunheira irrigada. Irriga, v.10, p.349-356, 2005.

Barcelos, E.; Rodrigues, M. R. L.; Santos, J. A. dos; Cunha, R. N. V. Produção de mudas de dendezeiro na Amazônia. Manaus: Embrapa Amazônia Ocidental, 2001. 11p. Circular Técnica 8.

Brasil. Ministério da Agricultura e do Abastecimento. Delegacia Federal de Agricultura no Pará. Comissão Estadual de Sementes e Mudas do Pará. Normas técnicas e padrões para a produção de mudas fiscalizadas no Estado do Pará. Belém, 1997. 40p.

Carvalho, C. M.; Viana, T. V. A.; Marinho, A. B.; Lima Júnior, L. A. de; Azevedo, B. M. de; Valnir Júnior, M. Influência de diferentes lâminas de irrigação no crescimento inicial do pinhão manso. Revista Brasileira de Agricultura Irrigada, v.5, p.75-81, 2011. http://dx.doi.org/10.7127/RBAI.V5N100017

Carvalho, K. S.; Pinheiro, H. A.; Festucci-Buselli, R. A.; Silva Júnior, D. D.; Castro, G. L. S.; Cruz, F. J. R.; Fujiyama, B. S. Diurnal changes in leaflet gas exchange, water status and antioxidant responses in Carapa guianensis plants under water-deficit conditions. Acta Physiologiae Plantarum, v.35, p.13-21, 2013. 
Chaves, M. M.; Flexas, J.; Pinheiro, C. Photosynthesis under drought and salt stress: Regulation mechanisms from whole plant to cell. Annals of Botany, v.103, p.103,551-560, 2009.

CONAB - Companhia Nacional de Abastecimento. Conjuntura mensal - açaí (fruto), http://www.conab.gov.br/OlalaCMS/uploads/ arquivos/14_08_05_11_07_18_acai_julho_2014.pdf, 13 Nov 2015.

Conforto, E. C.; Contin, D. R. Desenvolvimento do açaizeiro de terra firme, cultivar Pará, sob atenuação da radiação solar em fase de viveiro. Bragantia, v.68, p.979-983, 2009. http://dx.doi. org/10.1590/S0006-87052009000400018

Cordeiro, Y. E. M.; Pinheiro, H. A.; Santos Filho, B. G.; Correa, S. S.; Silva Júnior, D. D.; Dias Filho, M. B. Physiological and morphological responses of young mahogany (Swietenia macrophylla King) plants to drought. Forest Ecology and Management, v.258, p.1449-1455, 2009.

Fachini, E.; Galbiatti, J. A.; Pavani, L. C. Níveis de irrigação e de composto de lixo orgânico na formação de mudas cítricas em casa de vegetação. Engenharia Agrícola, v.24, p.578-588, 2004. http:// dx.doi.org/10.1590/S0100-69162004000300010

Gomes, F. P.; Oliva, M. A.; Mielke, M. S.; Almeida, A. A. F.; Aquino, L. A. Osmotic adjustment, proline accumulation and cell membrane stability in leaves of Cocos nucifera submitted to drought stress. Scientia Horticulturae, v.126, p.379-384, 2010.

Homma, A. K. O.; Nogueira, O. L.; Menezes, A. J. E. A.; Carvalho, J. E. U.; Nicoli, C. M. L.; Matos, G. B. Açaí: Novos desafios e tendências. Amazônia: Ciência e Desenvolvimento, v.1, p.7-23, 2006

Klar, A. E.; Villa Nova, N. A.; Marcos, Z. Z.; Cervellini, A. Determinação da umidade do solo pelo método das pesagens. Anais da Escola Superior de Agricultura Luiz de Queiroz, v.23, p.16-30, 1966.

Larcher, W. Ecofisiologia Vegetal. São Carlos: Rima, 2005. 550p.

Maia, C. E.; Levien, S. L. A. Estimativas de dimensões de bulbo molhado por gotejamento superficial aplicando modelo de superfície de resposta. Ciência Rural, v.40, p.1302-1308, 2010. http://dx.doi.org/10.1590/S0103-84782010005000099

Mar, C. C.; Conceição, H. E. O.; Santos, A. B. R.; Viégas, I. J. M.; Silva, F. S. N. Produção de massa seca e área foliar do açaizeiro sob déficit hídrico. Revista Agroecossistemas, v.5, p.14-23, 2013.

Menezes, E. M. S; Torres, A. T.; Srur, A. U. S. Valor nutricional da polpa de açaí (Euterpe oleraceae Mart) liofilizada. Acta Amazônica, v.38, p.311-316, 2008.

Murray, F. W. On the computation of saturation vapor pressure. Journal Applied of Meteorology, v.6, p.203-204, 1967.

Oliveira, M. S. P.; Farias Neto, J. T. Cultivar BRS-Pará: Açaizeiro para produção de frutos em terra firma. Belém: Embrapa Amazônia Oridental, 2004. 3p. Comunicado Técnico 114.

Parolin, P.; Simone, O. de; Haase, K.; Waldhoff, D.; Rottenberger, S.; Kuhn, U.; Kesselmeier, J.; Schmidt, W.; Piedade, M. T. F.; Junk, W. J. Central Amazon floodplain forests: Tree survival in a pulsing system. The Botanical Review, v.70, p.357-380, 2004.
Pinheiro, H. A.; DaMatta, F. M.; Chaves, A. R. M.; Loureiro, M. E.; Ducatti, C. Drought tolerance is associated with rooting depth and stomatal control of water use in clones of Coffea canephora. Annals of Botany, v.96, p.101-108, 2005.

Pinheiro, H. A.; Silva, J. V.; Endres, L.; Ferreira, V. M.; Câmara, C. A.; Cabral, F. F.; Oliveira, J. F.; Carvalho, L. W. T.; Santos, J. M.; Santos Filho, B. G. dos. Leaf gas exchange, chloroplastic pigments and dry matter accumulation in castor bean (Ricinus communis L.) seedlings subjected to salt stress conditions. Industrial Crops and Products, v.27, p.385-392, 2008. http://dx.doi.org/10.1016/j. indcrop.2007.10.003

Ramos, A.; Bovi, M. L. A.; Folegatti, M. V. Desenvolvimento vegetativo da pupunheira irrigada por gotejamento em função de níveis de depleção de água no solo. Horticultura Brasileira, v.20, p.28-33, 2002. http://dx.doi.org/10.1590/S0102-05362002000100005

SAEG - Sistema para Análises Estatísticas, Versão 9.1: Viçosa: Fundação Arthur Bernardes/ UFV, 2007.

SAGRI - Secretaria de Estado da Agricultura. Dados agropecuários de agricultura, culturas permanentes - açaí, http://www.sagri.pa.gov. br/pagina/agricultura, 13 Nov 2015.

Santana, A. C.; Costa, F. A. Mudanças recentes na oferta e demanda do açaí no Estado do Pará. In: Santana, A. C.; Carvalho, D. F.; Mendes, A. F. T. Análise sistêmica da fruticultura paraense: organização, mercado e competitividade empresarial. Belém: Banco da Amazônia, 2008. 255p.

Silva, P. A.; Oliveira, I. V.; Rodrigues, K. C. B.; Cosme, V. S.; Bastos, A. J. R.; Detmann, K. S. C.; Cunha, R. L.; Festucci-Buselli, R. A.; DaMatta, F. M.; Pinheiro, H. A. Leaf gas exchange and multiple enzymatic and non-enzymatic antioxidant strategies related to drought tolerance in two oil palm hybrids. Trees, v.30, p.203-214, 2016. http://dx.doi.org/10.1007/s00468-015-1289-x

Sousa, L. A. S.; Jardim, M. A. G. Produção foliar de mudas de açaizeiro (Euterpe oleraceae Mart.) em área de vegetação secundária no nordeste paraense. Revista Brasileira de Biociências, v.5, p.225227, 2007a.

Sousa, L. A. S.; Jardim, M. A. G. Sobrevivência e mortalidade de plântulas de açaizeiro (Euterpe oleraceae Mart.) cultivadas em capoeira no nordeste paraense. Revista Brasileira de Biociências, v.5, p.255-257, 2007b.

Suresh, K.; Nagamani, C.; Ramachanduru, K.; Mathur, R. K. Gasexchange characteristics, leaf water potential and chlorophyll a fluorescence in oil palm (Elaeis guineenses Jacq.) seedlings under water stress and recovery. Photosynthetica, v.48, p.430436, 2010.

Vellini, A. L. T. T.; Paula, N. F. de; Alves, P. L. C. A.; Pavani, L. C.; Bonine, C. A. V.; Scarpinati, E. A.; Paula, R. C. de. Respostas fisiológicas de diferentes clones de eucalipto sob diferentes regimes de irrigação. Revista Árvore, v.32, p.651-663, 2008. http:// dx.doi.org/10.1590/S0100-67622008000400006 